\title{
PENGARUH PARTISIPASI PENYUSUNAN ANGGARAN TERHADAP KINERJA MANAJERIAL (Studi pada Hotel di Kota Yogyakarta)
}

\author{
Eka Ningsih Puji Rahayu \\ Akademi AkuntansiLampung \\ email: ekaningsihpujirahayu@gmail.com
}

\begin{abstract}
This study aims to determine the effect of budgetary participation on managerial performance with decentralization, leadership style, and motivation as moderating variables. Primary data from 36 respondents consisting of hotel manager, heads of divisions and employees were obtained through direct survey from one hotel in Yogyakarta. Regression analysis were run four times to test four hypotheses. The results shows that only decentralization variable was found as moderating variable in strengthening the effect of budgetary participation on managerial performance.

Keywords: Participation in Budgeting, Managerial Performance, Decentralization, Leadership Style, Organizational Commitment, Motivation.
\end{abstract}

\section{Latar Belakang}

Yogyakarta dikenal sebagai kota pariwisata, selain itu Yogyakarta juga dikenal sebagai kota budaya. Tingginya tingkat budaya di kota Yogyakarta memberikan nilai tambah tersendiri bagi kota Yogyakarta. Hal ini menarik minat wisatawan lokal dan mancanegara untuk berkunjung ke Yogyakarta. Adanya itu semua memberikan peluang usaha bagi para penyedia jasa, terutama jasa perhotelan. Hal ini tidak terlepas dari peran manajemen hotel tersebut karena usaha hotel didasari oleh konsep, fungsi dan strategi manajemen dalam menghadapi pesaingnya. Strategi tersebut pada dasarnya bertujuan untuk dapat meningkatkan kinerja hotel. Peningkatan kinerja merupakan salah satu faktor yang berperan penting dalam memajukan daya saing dalam dunia usaha yang tentunya tidak terlepas dari tanggung jawab manajer dan partisipasi para kepala unit bagian.

Kinerja manajerial dalam perusahaan dihubungkan dengan partisipasinya dalam penyusunan anggaran. Pada Pernyataan Milani (1975) dalam Nor (2007: 2) penyusunan anggaran secara partisipatif diharapkan dapat meningkatkan kinerja manajer, yaitu ketika suatu tujuan dirancang dan secara partisipasi disetujui maka karyawan akan menginternalisasikan tujuan yang ditetapkan dan memiliki rasa tanggung jawab pribadi untuk mencapainya, karena mereka ikut terlibat dalam penyusunan anggaran.

Telah banyak yang melakukan penelitian tentang hubungan partisipasi anggaran dengan kinerja diantaranya Kenis, 1979; Brownell, 1982; Brownell dan MccInnes 1986; Frucot dan Shearon, 1991; Indriantoro, 1995; menemukan bahwa partisipasi penganggaran dan kinerja memiliki hubungan yang sangat positif, sedangkan Sterdy, 1960; Bryan dan Locke, 1967; Chenhall dan Brownell, 1988; Milani, 1975 dikutip dalam Nor (2007: 3) menemukan partisipasi penganggaran tidak meningkatkan kinerja. Sardjito (2005) dan Dr. Eker (2008) dikutip dalam Ratri (2010: 17) melakukan pengujian partisipasi anggaran dan kinerja manajerial dengan komitmen organisasi dimana variabel tersebut berpengaruh secara signifikan.

Hasil penelitian Mia (1988) dalam Poerwati (2001: 7) menunjukkan bahwa motivasi sebagai variabel moderating mempengaruhi secara signifikan partisipasi penyusunan anggaran terhadap kinerja manjerial. Poerwati (2001) dalam penelitiannya menemukan bahwa motivasi tidak memoderasi pengaruh partisipasi penyusunan anggaran terhadap 
kinerja manajerial. Penelitian Nor (2007) yang menemukan bahwa partisipasi penyusunan anggaran berpengaruh positif signifikan terhadap kinerja manajerial.

Hasil penelitian yang telah diuraikan di atas menunjukkan bahwa hasil temuan yang tidak konsisten antara satu dengan lainnya, sehingga para peneliti menyimpulkan bahwa tidak ada hubungan langsung yang sederhana antara partisipasi dan kinerja (Gul dkk., 1995 dalam nor, 2007: 3). Menurut Chong dan Chong (2002) dan Early dan Kanfer (1985) dalam Ratri (2010: 1718) partisipasi penyusunan anggaran mempunyai pengaruh tidak langsung dengan kinerja manajerial. Hal ini sering menimbulkan kontradiksi. Pendekatan kontijensi (contingency approach) dapat dipergunakan untuk menyelesaikan perbedaan dari berbagai penelitian tersebut (Govindarajan (1986a) dalam Nor (2007: 3). Pendekatan kontijensi memungkinkan adanya variabelvariabel lain yang dapat bertindak sebagai faktor moderating atau intervening yang mempengaruhi hubungan antara partisipasi anggaran dengan kinerja manajerial (Brownell, 1982a; Murray, 1990; Shield dan Young, 1993 d dalam Nor 2007: 3). Variabel desentralisasi, gaya kepemimpinan, komitmen organisasi dan motivasi merupakan variabel yang dapat memoderasi hubungan antara partisipasi penyusunan anggaran dan kinerja manajerial.

Menurut Galbraith (1973 dalam Nor 2007: 3) struktur organisasi yang terdesentralisasi diperlukan pada kondisi administratif, tugas dan tanggung jawab yang semakin kompleks, yang selanjutnya memerlukan pendistribusian otoritas pada manajemen yang lebih rendah. Para bawahan atau karyawan dalam hal ini memegang peranan penting dalam pengambilan keputusan selain wewenang dan otoritas yang dimiliki oleh manajer. Keberhasilan suatu organisasi tidak dapat terlepas dari peran pemimpin dalam mengelola suatu organisasi dan sikap bawahan dalam mengimplementasikan peran dan tanggung jawabnya dalam upaya pencapaian citacita perusahaan. Menurut Decoster dan Fertakis (1968) dalam Nor (2007: 4) menyatakan bahwa kepemimpinan yang efektif harus memberikan pengarahan terhadap usahausaha dalam mencapai tujuan organisasi. Selain itu, komitmen yang tinggi sangat diperlukan pada sebuah perusahaan karena sangat mempengaruhi kerja yang profesional. Suatu perusahaan dapat lebih mudah mencapai tujuan jika karyawan berkomitmen tinggi pada perusahaan. Memahami motivasi juga merupakan tugas penting manajer, karena manajer bertindak melalui orang lain (Hanafi, 2003: 306).

Setelah mempelajari beberapa penelitian sebelumnya peneliti terinspirasi dari penelitian Andarini (2005) tentang motivasi, gaya kepemimpinan dan desentralisasi sebagai variabel pemoderasi antara partisipasi penyusunan anggaran dengan kinerja pada organisasi sektor publik dengan studi empiris Kota Yogyakarta. Peneliti tertarik untuk mereplikasi penelitian tersebut dengan perbedaan menambahkan variabel motivasi sebagai variabel moderating dan mengambil objek studi pada sektor swasta yaitu pada perusahaan jasa perhotelan di kota Yogyakarta. Pemilihan obyek ini karena hotel tidak terlepas dari penggunaan anggaran untuk mencapai tujuan perusahaan.

\section{Kajian Literatur}

\section{Partisipasi Penyusunan Anggaran}

Anggaran mempunyai dua peran penting dalam perusahaan, di satu sisi anggaran berperan sebagai alat untuk perencanaan (Planning) dan di satu sisi anggaran berperan sebagai alat untuk pengendalian (Halim, Tjahjono dan Husein; 2000: 173). Menurut Milani (1975) dikutip dalam Poerwati (2001: 10), partisipasi penyusunan anggaran yaitu seberapa jauh anggaran dipengaruhi oleh keterlibatan para manajer, alasanalasan para atasan pada waktu anggaran dalam proses revisi, frekuensi menyatakan inisiatif, memberikan usulan dan atau pendapat tentang anggaran kepada atasan tanpa diminta, seberapa jauh manajer merasa mempunyai pengaruh dalam anggaran final, kepentingan manajer dalam kontribusinya pada 
anggaran, dan frekuensi anggaran didiskusikan oleh para atasan pada waktu anggaran disusun.

\section{Kinerja Manajerial}

Menurut Mahoney dkk (1963) dalam Suprantiningrum dan Zulaikha (2002) dikutip dalam Hapsari, Arum, dan Murtanto (2005: 5) kinerja manajerial adalah kinerja para individu anggota organisasi dalam kegiatankegiatan manajerial, antara lain: perencanaan, investigasi, koordinasi, supervisi, pengaturan staff (staffing), negosiasi, dan representasi. Ada beberapa faktor yang dapat mempengaruhi kinerja manajerial menurut Amstrong dan Baron (1998) dalam Ratri (2010: 3536) antara lain faktor Pribadi (keahlian, kepercayaan diri, motivasi dan komitmen), faktor Kepemimpinan (kualitas keberanian/semangat, pedoman pemberian semangat pada manajer dan pemimpin kelompok organisasi), faktor tim/kelompok (sistem pekerjaan dan fasilitas yang disediakan oleh organisasi), faktor Situasional (perubahan dan tekanan dari lingkungan internal dan eksternal).

\section{Desentralisasi}

Desentralisasi merupakan representasi dari wujud adanya pelimpahan kewenangan dari hierarki yang lebih tinggi kepada hierarki yang lebih rendah dalam hal pengambilan keputusan dan penentuan dengan cara bagaimana kegiatan akan dijalankan (Sule dan Saefullah, 2005: 184). Terdapat banyak alasan dibalik keputusan melakukan desentralisasi diantaranya kemudahan terhadap pengumpulan dan pemanfaatan informasi lokal, fokus manajemen pusat, melatih dan memotivasi para manajer segmen, meningkatkan daya saing, terbukanya segmensegmen kepada berbagai kekuatan pasar (Hansen, R, Mowen dan Hermawan 2000: 65).

\section{Gaya Kepemimpinan}

Gaya kepemimpinan adalah pola tingkah laku yang dirancang untuk mengintegrasikan tujuan organisasi dengan tujuan individu untuk mencapai tujuan tertentu (kotter, 1990, halaman 5) dikutip dalam Lapuga (2011: 15). Jika kepemimpinan tersebut terjadi pada suatu organisasi formal tertentu, pemimpin perlu mengembangkan karyawan, membangun iklim motivasi, menjalankan fungsifungsi manajerial dalam rangka menghasilkan kinerja yang tinggi dan meningkatkan kinerja perusahaan maka pemimpin perlu menyesuaikan gaya kepemimpinannya (Siagian, 2002) dikutip dalam (Ramdhani: 12).

\section{Komitmen Organisasi}

Steers (1985) dalam Ratri (2010: 38) mendefinisikan komitmen organisasi sebagai rasa identifikasi (kepercayaan terhadap nilainilai organisasi), keterlibatan (kesediaan untuk berusaha sebaik mungkin demi kepentingan organisasi) dan loyalitas (keinginan untuk tetap menjadi anggota organisasi yang bersangkutan) yang dinyatakan oleh seorang pegawai terhadap organisasinya.

\section{Motivasi}

Menurut Goleman (2003) dalam Nuraini (2007) dikutip dalam Windari (2011) Motivasi didefinisikan sebagai suatu konsep yang digunakan jika memulai dan mengarahkan perilaku atau segala sikap yang menjadi pendorong timbulnya suatu perilaku.

\section{Pengembangan Hipotesis}

\section{a. Hubungan Partisipasi Penyusunan Anggaran dan Kinerja Manajerial}

Milani (1975) dikutip dalam Ratri (2010: 44) partisipasi penyusunan anggaran diharapkan meningkatkan kinerja manajerial, yakni ketika tujuan telah direncanakan dan disetujui secara partisipatif, karyawan akan menginternalisasi tujuan tersebut dan mereka akan memiliki tanggung jawab secara personal untuk mencapainya melalui keterlibatan dalam proses anggaran. Partisipasi anggaran dapat meningkatkan kinerja manajerial dan partisipasi dapat mempermudah bawahan untuk berkomunikasi kepada atasannya tentang 
segala kebutuhan yang mereka perlukan. Partisipasi dalam penyusunan anggaran juga memungkinkan tercapainya kinerja manajerial yang bagus. Nor (2007) dalam penelitiannya menemukan bahwa ada pengaruh positif signifikan antara variabel dependen (kinerja manajerial) dengan variabel independen (partisipasi penyusunan anggaran). Hubungan yang ditunjukkan oleh koefisien regresi yang positif signifikan, artinya kalau partisipasi dalam penyusunan anggaran meningkat maka kinerja manajerial juga akan meningkat. Berdasarkan uraian di atas hipotesis yang diajukan adalah:

$\mathbf{H}_{1}$ : Partisipasi penyusunan anggaran berpengaruh terhadap kinerja manajerial

\section{b. Desentralisasi, Partisipasi Penyusunan Anggaran dan Kinerja Manajerial}

Menurut Hapsari dan Murtanto (2005: 6) Proses penyusunan anggaran merupakan kegiatan yang penting dan melibatkan berbagai pihak baik manajer tingkat atas maupun manajer tingkat bawah (desentralisasi) yang akan memainkan peranan dalam mempersiapkan dan mengevaluasi berbagai alternatif dari tujuan anggaran, dimana anggaran senantiasa digunakan sebagai tolak ukur terbaik kinerja manajer. Desentralisasi hanyalah istilah dalam organisasi yang didefinisikan sebagai penyerahan kewenangan. Miah dan Mia (1996) dikutip dalam Nor (2007: 7) Desentralisasi adalah seberapa jauh manajer yang lebih tinggi mengizinkan manajer dibawahnya untuk mengambil keputusan secara independen. Desentralisasi biasanya diwujudkan melalui pembentukan unitunit yang disebut divisi (Hansen dan Mowen 2000: 67). Hasil penelitian yang dilakukan oleh Slamet Riyadi (2000) dikutip dalam Hapsari dan Murtanto (2005: 67) juga menemukan bahwa pengaruh partisipasi dalam proses penyusunan anggaran terhadap kinerja manajerial akan tinggi apabila pelimpahan wewenang yang diberikan pada tingkat desentralisasi yang tinggi. Berdasarkan uraian di atas Hipotesis yang diajukan adalah:

$\mathbf{H}_{2}$ : Desentralisasi memperkuat hubungan antara partisipasi penyusunan anggaran terhadap kinerja manajerial

\section{c. Gaya Kepemimpinan, Partisipasi Penyusunan Anggaran dan Kinerja Manajerial}

Menurut Decoster dan Fertakis (1968) dikutip dalam Nor (2007) gaya kepemimpinan dapat dibagi dalam dua dimensi yaitu pertama, struktur inisiatif (initiating sructure) yang menunjukkan prilaku pemimpin yang dihubungkan dengan kinerja pekerjaan yang kedua, gaya kepemimpinan pertimbangan (consideration) yang menunjukkan hubungan dekat, saling mempercayai dan saling memperhatikan antara pimpinan dan bawahan. Sedangkan menurut pendekatan teori pathgoal seseorang pemimpin membutuhkan fleksibilitas dalam menggunakan gaya apapun yang sesuai dengan situasi tertentu (Nor, 2007). Gaya kepemimpinan yang baik dalam partisipasi anggaran dapat meningkatkan kinerja manjerial. Berdasarkan uraian di atas hipotesis yang diajukan adalah:

$\mathbf{H}_{3}$ : Gaya kepemimpinan memperkuat hubungan antara partisipasi penyusunan anggaran terhadap kinerja manajerial.

\section{d. Komitmen Organisasi, Partisipasi Penyusunan Anggaran dan Kinerja Manajerial}

Komitmen organisasi merupakan nilai personal, yang kadangkadang mengacu pada sikap loyal pada perusahaan atau komitmen pada perusahaan (Ratri, 2010: 37). Adanya komitmen organisasi yang kuat dari dalam diri individu akan membuat seorang individu untuk berusaha keras dalam mencapai tujuan organisasi. Sebaliknya, jika individu mempunyai komitmen organisasi yang rendah maka akan mempunyai perhatian yang lemah terhadap pencapaian tujuan organisasi. Komitmen organisasi yang kuat mendorong individu berusaha keras mencapai tujuan organisai (Angel dan Perry, 1981; Porter et.al., 1974) dikutip dalam (Ratri, 2010: 45). Apabila komitmen organisasi melibatkan kepercayaan dan keterterimaan tujuan organisasi, maka partisipasi dalam penyusunan anggaran dapat 
meningkatkan komitmen organisasi (Ratri, 2010: 46). Berdasarkan uraian di atas hipotesis yang diajukan adalah:

$\mathbf{H}_{4}$ : Komitmen organisasi memperkuat hubungan antara partisipasi penyusunan anggaran terhadap kinerja manajerial.

\section{e. Motivasi, Partisipasi Penyusunan Anggaran dan Kinerja Manajerial}

Menurut Ghozali dan Pradana Adi Putra (2002) dikutip dalam Adrianto (2008: 21) motivasi merupakan derajat sampai dimana seorang individu ingin dan berusaha untuk melaksanakan suatu tugas atau pekerjaan dengan baik dan kesediaan untuk mengeluarkan tingkat upaya yang tinggi ke arah tujuan organisasi, yang dikondisikan oleh kemampuan upaya itu untuk memenuhi suatu kebutuhan individual. Menurut Halim dan Supomo (1990: 168) anggaran berfungsi juga sebagai alat pendorong yang dapat membangkitkan motivasi para manajer dalam mencapai tujuan pusat pertanggungjawaban yang dipimpinnya dan tujuan perusahaan secara keseluruhan. Menurutnya motivasi tersebut akan meningkat jika para manajer berperan secara aktif dalam menyusun dan melaksanakan anggaran perusahaan. Hasil penelitian Ghazali dan putra (2002) dalam Rosmayanti (2001:22) menunjukkan bahwa motivasi berperan sebagai variabel moderating terhadap pengaruh positif antara partisipasi penyusunan anggaran dan kinerja manajerial. Penelitian yang dilakukan oleh Mia dalam Riyadi (2000) dalam Nor (2007) menunjukkan secara signifikan motivasi mampu bertindak sebagai variabel moderating di dalam hubungan antara partisipasi penyusunan anggaran dengan kinerja manajerial. Berdasarkan uraian di atas maka hipotesis yang diajukan adalah:

H5: Motivasi memperkuat hubungan antara partisipasi penyusunan anggaran terhadap kinerja manajerial

\section{Metoda Penelitian}

Pada penelitian ini teknik pengambilan sampel menggunakan purposive sampling. Adapun kriteria dalam pengambilan sampel yaitu manajer, kepala bagian/ divisi dan karyawan yang terlibat dalam proses penyusunan anggaran. Jenis data dalam penelitian ini berupa data kuantitatif. Sumber data yang digunakan adalah data primer. Teknik pengumpulan data dengan menggunakan metoda survei dengan instrumen yang digunakan dalam memperoleh data yaitu kuesioner yang dibagikan kepada sampel.

\section{Definisi Operasional Variabel}

Partisipasi dalam penyusunan anggaran berkaitan dengan seberapa jauh keterlibatan manajer di dalam menentukan atau menyusun anggaran yang ada dalam departemen atau bagiannya, baik secara periodik maupun tahunan (Nor, 2007). Instrumen yang digunakan dalam mengukur variabel ini diadopsi dari Milani (1975) dikutip dalam Andarini (2005).

Kinerja merupakan prestasi yang diperlihatkan atau kemampuan kerja seseorang (Adoe, 2001) dikutip dalam Andarini (2005). Instrumen diukur dengan menggunakan kuesioner "self rating" yang dikembangkan oleh Mahoney et.al., (1963) dalam Hafiz (2007) dalam Rosmayanti (2011).

Desentralisasi merupakan representasi dari wujud adanya pelimpahan kewenangan dari hierarki yang lebih tinggi kepada hierarki yang lebih rendah dalam hal pengambilan keputusan dan penentuan dengan cara bagaimana kegiatan akan dijalankan (Sule dan Saefullah, 2005: 184). Variabel ini diukur dengan menggunakan instrumen yang telah dikembangkan Gordon dan Narayanan (1984) dalam Andarini (2005).

Gaya kepemimpinan adalah perilaku atau tindakan manajer dalam berinteraksi terhadap bawahannya. Istrumen yang digunakan dalam pengukuran variabel ini adalah instrumen yang dikembangkan oleh likert (1967) dalam luthans (1998) dalam Andarini (2005). 
Komitmen organisasi dapat diartikan sebagai perasaan suka dan loyalitas seorang karyawan terhadap perusahaan dan ketersediaannya melakukan sesuatu demi kepentingan perusahaannya. Instrumen yang digunakan dalam pengukuran variabel ini adalah instrumen yang telahdikembangkan oleh Mowday et.al., (1979) dalam Nurcahyani, (2010) dalam Rosmayanti (2011: 32).

Motivasi didefinisikan sebagai suatu konsep yang digunakan jika memulai dan mengarahkan perilaku atau segala sikap yang menjadi pendorong timbulnya suatu perilaku (Goleman, 2003) dalam Nuraini (2007) dikutip dalam Windari (2011). Instrumen yang digunakan dalam penelitian ini adalah teori kebutuhan Aldefer (luthans, 1998) dalam Andarini (2005). Dalam teori ini kebutuhan manusia dibedakan menjadi tiga tingkatan, yaitu: (1) Kebutuhan eksistensi (existence needs), antara lain: gaji, kondisi kerja, (2) Kebutuhan hubungan (related needs), antara lain: hubungan pribadi di tempat kerja, dan (3) kebutuhan pertumbuhan (growth needs), antara lain pengembangan potensi diri (Andarini, 2005).

\section{Hasil dan Pembahasan}

\section{Pengujian Instrumen}

Pada penelitian ini uji validitas dilakukan dengan membandingkan nilai $r$ tabel dan $r$ hitung untuk degree of freedom $(\mathrm{df})=\mathrm{n} 2$, dalam hal ini $\mathrm{n}$ adalah jumlah sampel Jumlah sampel dalam penelitian ini adalah 36 maka $\mathrm{df}=362$ jadi $\mathrm{df}=34$, nilai signifikansi $5 \%$ maka nilai $r$ tabel adalah 0,329. Pada penelitian ini nilai $r$ hitung lebih besar dari nilai $r$ tabel maka dapat disimpulkan bahwa setiap butir pertanyaan pada kuesioner valid untuk mengukur apa yang seharusnya diukur.

Tabel 1

Pengujian Validitas

\begin{tabular}{|c|c|c|c|}
\hline Variabel & Item & r hitung & r tabel \\
\hline PPA & PPA1 & $\mathbf{0 , 6 0 2}$ & $\mathbf{0 , 3 2 9}$ \\
\hline & PPA 2 & $\mathbf{0 , 3 7 5}$ & $\mathbf{0 , 3 2 9}$ \\
\hline & PPA 3 & $\mathbf{0 , 5 2 2}$ & $\mathbf{0 , 3 2 9}$ \\
\hline & PPA 4 & $\mathbf{0 , 6 8 9}$ & $\mathbf{0 , 3 2 9}$ \\
\hline & PPA 5 & $\mathbf{0 , 4 5 9}$ & $\mathbf{0 , 3 2 9}$ \\
\hline & PPA 6 & $\mathbf{0 , 5 7 9}$ & $\mathbf{0 , 3 2 9}$ \\
\hline Des & Des 1 & $\mathbf{0 , 4 2 0}$ & $\mathbf{0 , 3 2 9}$ \\
\hline & Des 2 & $\mathbf{0 , 6 2 3}$ & $\mathbf{0 , 3 2 9}$ \\
\hline & Des 3 & $\mathbf{0 , 3 6 4}$ & $\mathbf{0 , 3 2 9}$ \\
\hline & Des 4 & $\mathbf{0 , 4 5 5}$ & $\mathbf{0 , 3 2 9}$ \\
\hline & Des 5 & $\mathbf{0 , 4 9 5}$ & $\mathbf{0 , 3 2 9}$ \\
\hline GK 1 & $\mathbf{0 , 6 9 3}$ & $\mathbf{0 , 3 2 9}$ \\
\hline & GK 2 & $\mathbf{0 , 4 1 0}$ & $\mathbf{0 , 3 2 9}$ \\
\hline & GK 3 & $\mathbf{0 , 3 7 6}$ & $\mathbf{0 , 3 2 9}$ \\
\hline & GK 4 & $\mathbf{0 , 5 0 3}$ & $\mathbf{0 , 3 2 9}$ \\
\hline & GK 5 & $\mathbf{0 , 5 8 9}$ & $\mathbf{0 , 3 2 9}$ \\
\hline & GK 6 & $\mathbf{0 , 3 4 7}$ & $\mathbf{0 , 3 2 9}$ \\
\hline & GK 7 & $\mathbf{0 , 6 1 3}$ & $\mathbf{0 , 3 2 9}$ \\
\hline & GK 8 & $\mathbf{0 , 5 4 4}$ & $\mathbf{0 , 3 2 9}$ \\
\hline & GK 9 & $\mathbf{0 , 5 6 9}$ & $\mathbf{0 , 3 2 9}$ \\
\hline & GK 10 & $\mathbf{0 , 5 9 7}$ & $\mathbf{0 , 3 2 9}$ \\
\hline & GK 11 & $\mathbf{0 , 4 1 6}$ & $\mathbf{0 , 3 2 9}$ \\
\hline & GK 12 & $\mathbf{0 , 6 4 7}$ & $\mathbf{0 , 3 2 9}$ \\
\hline & GK 13 & $\mathbf{0 , 4 6 9}$ & $\mathbf{0 , 3 2 9}$ \\
\hline & GK 14 & $\mathbf{0 , 4 7 7}$ & $\mathbf{0 , 3 2 9}$ \\
\hline & GK 15 & $\mathbf{0 , 4 5 8}$ & $\mathbf{0 , 3 2 9}$ \\
\hline KO 1 & $\mathbf{0 , 3 5 4}$ & $\mathbf{0 , 3 2 9}$ \\
\hline KO & KO 2 & $\mathbf{0 , 3 6 4}$ & $\mathbf{0 , 3 2 9}$ \\
\hline & 59 & \\
\hline & &
\end{tabular}


Jurnal REKSA : Rekayasa Keuangan, Syariah, dan Audit (Volume 5 No 1 Tahun 2018)

\begin{tabular}{|c|c|c|c|}
\hline & KO 3 & 0,331 & 0,329 \\
\hline & KO 4 & 0,502 & 0,329 \\
\hline & KO 5 & 0,519 & 0,329 \\
\hline & KO 6 & $\mathbf{0 , 3 9 1}$ & 0,329 \\
\hline & KO 7 & 0,617 & 0,329 \\
\hline & KO 8 & 0,360 & 0,329 \\
\hline & KO 9 & 0,469 & 0,329 \\
\hline & KO 10 & 0,391 & 0,329 \\
\hline & KO 11 & 0,424 & 0,329 \\
\hline & KO 12 & 0,342 & 0,329 \\
\hline & KO 13 & 0,597 & 0,329 \\
\hline \multirow[t]{6}{*}{ Mot } & MOT 1 & 0,777 & 0,329 \\
\hline & MOT 2 & 0,458 & 0,329 \\
\hline & MOT 3 & 0,525 & 0,329 \\
\hline & MOT 4 & 0,633 & 0,329 \\
\hline & MOT 5 & 0,484 & 0,329 \\
\hline & MOT 6 & 0,661 & 0,329 \\
\hline \multirow[t]{8}{*}{$\mathbf{K M}$} & KM 1 & 0,385 & 0,329 \\
\hline & KM 2 & 0,780 & 0,329 \\
\hline & KM 3 & 0,611 & 0,329 \\
\hline & KM 4 & 0,723 & 0,329 \\
\hline & KM 5 & 0,679 & 0,329 \\
\hline & KM 6 & 0,638 & 0,329 \\
\hline & KM 7 & 0,556 & 0,329 \\
\hline & KM 8 & 0,360 & 0,329 \\
\hline
\end{tabular}

Sumber: Data diolah (2018)

Keterangan:

PPA : Partisipasi Penyusunan Anggaran

Des : Desentralisasi

GK : Gaya Kepemimpinan

KO : Komitmen Organisasi

Mot : Motivasi

KM : Kinerja Manajerial

Tabel 2

Pengujian Reliabilitas

\begin{tabular}{|l|c|}
\hline \multicolumn{1}{|c|}{ Variabel } & $\begin{array}{c}\text { Cronbach } \\
\text { Alpha }\end{array}$ \\
\hline PPA & 0,776 \\
\hline Desentralisasi & 0,706 \\
\hline GK & 0,868 \\
\hline KO & 0,803 \\
\hline Motivasi & 0,821 \\
\hline Kinerja Manajerial & 0,848 \\
\hline
\end{tabular}

Sumber: Data diolah (2018)

Berdasarkan hasil output pada tabel 2 dapat dilihat bahwa uji reliabilitas nilainya lebih dari 0,60. Dapat disimpulkan bahwa instrumen dinyatakan reliabel.

Tabel 3

Pengujian Normalitas 
Jurnal REKSA : Rekayasa Keuangan, Syariah, dan Audit (Volume 5 No 1 Tahun 2018)

\begin{tabular}{|c|c|c|}
\hline & & $\begin{array}{l}\text { Unstandard } \\
\text { iz Residual }\end{array}$ \\
\hline \multicolumn{2}{|l|}{$\mathrm{N}$} & 36 \\
\hline \multirow{2}{*}{$\begin{array}{l}\text { Normal } \\
\text { Parameters }\end{array}$} & Mean & .0000000 \\
\hline & $\begin{array}{l}\text { Std. } \\
\text { Deviation }\end{array}$ & 3.56989076 \\
\hline \multirow{3}{*}{$\begin{array}{l}\text { Most } \\
\text { Differences }\end{array}$} & Absolute & .160 \\
\hline & Positive & .132 \\
\hline & Negative & -.160 \\
\hline \multicolumn{2}{|c|}{ Kolmogorov-Smirnov Z } & .957 \\
\hline \multicolumn{2}{|c|}{ Asymp. Sig. (2-tailed) } & .318 \\
\hline
\end{tabular}

a. Test distribution is Normal.

Sumber: Data diolah (2018)

Pada tabel 3 diketahui bahwa hasil uji normalitas nilai signifikansinya 0,318 maka dapat disimpulkan bahwa data berdistribusi normal.

Tabel 4

Pengujian Autokorelasi

\begin{tabular}{|c|c|c|c|c|}
\hline \multicolumn{5}{|c|}{ Model Summary ${ }^{b}$} \\
\hline Model & $\mathrm{R}$ & R Square & $\begin{array}{c}\text { Adjusted R } \\
\text { Square }\end{array}$ & $\begin{array}{l}\text { Durbin- } \\
\text { Watson }\end{array}$ \\
\hline 1 & $.089^{\mathrm{a}}$ & .008 & -.021 & 1.904 \\
\hline
\end{tabular}

Sumber: Data diolah (2018)

Pada tabel 5 dapat dilihat nilai 1,525 $<1,904<2,475$. Maka dapat disimpulkan bahwa tidak ada autokolerasi dalam model ini.

Tabel 5

Pengujian Heteroskedastisitas

Coefficients $^{\mathrm{a}}$

\begin{tabular}{|c|c|c|c|c|c|}
\hline \multirow[b]{2}{*}{ Model } & \multicolumn{2}{|c|}{$\begin{array}{l}\text { Unstandardiz } \\
\text { Coefficients }\end{array}$} & \multirow{2}{*}{$\begin{array}{c}\text { Standardized } \\
\text { Coefficients }\end{array}$} & \multirow[b]{2}{*}{$\mathrm{t}$} & \multirow[b]{2}{*}{ Sig. } \\
\hline & B & Error & & & \\
\hline 1 (Constant) & 3.141 & 3.662 & & .858 & .397 \\
\hline PPA & .030 & .166 & .031 & .179 & .859 \\
\hline
\end{tabular}

Sumber: Data diolah (2018)

Berdasarkan tabel 5 didapat nilai signifikansi 0,859 dan jelas $0,05<0,859$. Hal ini dapat disimpulkan bahwa tidak ada heteroskedastisitas.

2. Pengujian Hipotesis

\section{Tabel 6}

Hasil uji Determinasi

Partisipasi Penyusunan Anggaran Terhadap Kinerja Manajerial

Model Summary

\begin{tabular}{|l|l|r|r|r|}
\hline Model & $\mathrm{R}$ & R Square & $\begin{array}{r}\text { Adjusted } \\
\text { R Square }\end{array}$ & $\begin{array}{l}\text { Std. Error of } \\
\text { the Estimate }\end{array}$ \\
\hline 1 & $.089^{\mathrm{a}}$ & .008 & .021 & 3.622 \\
\hline
\end{tabular}

a. Predictors: (Constant), PPA

Sumber: Data diolah (2018) 
Pada tabel 6 diketahui nilai Adjusted R Square sebesar 0,021 atau 2,1\%. Hasil ini berarti kurang dari nol dan dapat disimpulkan bahwa kemampuan variabelvariabel independen tidak dapat menjelaskan variabel dependen.

\section{Tabel 7}

Hasil uji Determinasi

Desentralisasi Memperkuat Hubungan Antara Partisipasi Penyusunan Anggaran Terhadap Kinerja Manajerial

\begin{tabular}{|l|c|r|r|r|}
\hline Model & $\mathrm{R}$ & $\begin{array}{c}\mathrm{R} \\
\text { Square }\end{array}$ & $\begin{array}{c}\text { Adjusted R } \\
\text { Square }\end{array}$ & $\begin{array}{l}\text { Std. Error of } \\
\text { the Estimate }\end{array}$ \\
\hline 1 & $.419^{\mathrm{a}}$ & .175 & .125 & 3.352 \\
\hline
\end{tabular}

Sumber: Data diolah (2018)

Berdasarkan tabel 7 dapat dilihat nilai Adjusted $R$ Square sebesar 0,125 atau 12,5\%. Hal ini berarti kinerja manajerial dapat dijelaskan oleh variabel independen partisipasi penyusunan anggaran dan desentralisasi.

\section{Tabel 8}

\section{Hasil uji Determinasi}

Gaya Kepemimpinan Memperkuat Hubungan Antara Partisipasi Penyusunan Anggaran Terhadap Kinerja Manajerial

\begin{tabular}{|l|l|r|r|r|}
\hline \multicolumn{5}{|c|}{ Model Summary } \\
Model & $\mathrm{R}$ & $\begin{array}{c}\mathrm{R} \\
\text { Square }\end{array}$ & $\begin{array}{c}\text { Adjusted } \\
\text { R Square }\end{array}$ & $\begin{array}{l}\text { Std. Error of } \\
\text { the Estimate }\end{array}$ \\
\hline 1 & $.264^{\mathrm{a}}$ & .070 & .013 & 3.560 \\
\hline
\end{tabular}

a. Predictors: (Constant), Moderat2, PPA

Sumber: Data diolah (2018)

Berdasarkan tabel 8 dapat dilihat nilai Adjusted $R$ Square sebesar 0,013 atau 1,3\%. Hasil ini berarti kurang dari nol dan dapat disimpulkan bahwa kemampuan variabel gaya kepemimpinan dan partisipasi penyusunan anggaran dapat menjelaskan variabel kinerja manajerial.

\section{Tabel 9}

Hasil uji Determinasi

\section{Komitmen Organisasi Memperkuat Hubungan Antara Partisipasi Penyusunan} Anggaran Terhadap Kinerja Manajerial

\begin{tabular}{|l|l|r|r|r|}
\hline & & $\begin{array}{c}\text { R } \\
\text { Model }\end{array}$ & $\mathrm{R}$ & Adjusted \\
Square & R Square & $\begin{array}{l}\text { Std. Error of } \\
\text { the Estimate }\end{array}$ \\
\hline 1 & $.118^{\mathrm{a}}$ & .014 & .046 & 3.666 \\
\hline
\end{tabular}

Sumber: Data diolah (2018)

Berdasarkan tabel 9 dapat dilihat nilai Adjusted $R$ Square sebesar 0,046 atau 4,6\%. Hasil ini berarti kurang dari nol dan dapat disimpulkan bahwa variabel komitmen organisasi dan parisipasi penyusunan anggaran tidak dapat menjelaskan variabel independen yaitu variabel kinerja manajerial. 


\section{Motivasi Memperkuat Hubungan Antara Partisipasi Penyusunan Anggaran Terhadap Kinerja Manajerial \\ Model Summary

\begin{tabular}{|l|l|r|r|r|}
\hline Model & \multicolumn{1}{|c|}{$\mathrm{R}$} & $\begin{array}{c}\mathrm{R} \\
\text { Square }\end{array}$ & $\begin{array}{r}\text { Adjusted } \\
\text { R Square }\end{array}$ & $\begin{array}{c}\text { Std. Error of } \\
\text { the Estimate }\end{array}$ \\
\hline 1 & $.180^{\mathrm{a}}$ & .032 & .026 & 3.631 \\
\hline
\end{tabular}

a. Predictors: (Constant), Moderat4, PPA

\section{Sumber: Data diolah (2018)}

Pada tabel 10 didapat nilai Adjusted $R$ Square sebesar 0,026 atau 2,6\%. Hasil ini berarti kurang dari nol dan dapat disimpulkan bahwa kemampuan variabelvariabel independen tidak dapat menjelaskan variabel dependen.

Pengujian hipotesis partisipasi penyusunan anggaran berpengaruh terhadap kinerja manajerial menunjukkan nilai $t$ hitung sebesar 0,523 dengan nilai signifikansi 0,604 dapat disimpulkan bahwa hipotesis pertama ditolak. Hal ini sejalan dengan penelitian yang dilakukan (Harmonis, 2011) bahwa secara parsial partisipasi anggaran tidak berpengaruh terhadap kinerja manajerial.

Hipotesis desentralisasi memperkuat hubungan antara partisipasi penyusunan anggaran terhadap kinerja manajerial menunjukkan nilai t hitung sebesar 2,587 dan nilai signifikansi sebesar 0,014 berarti hipotesis 2 diterima. Hal ini menolak penelitian yang dilakukan oleh (Nor, 2007) Semakin tinggi (rendah) tingkat kesesuaian antara partisipasi penyusunan anggaran dengan desentralisasi, semakin tinggi (rendah) kinerja manajerial. Hal ini dikarenakan tingkat pendelegasian wewenang dan tanggung jawab yang diberikan kepada karyawan dalam pengambilan keputusan pada hotel di kota Yogyakarta dalam penyusunan anggaran dapat meningkatkan kinerja manajerial. Desentralisasi dapat meningkatkan kompetisi bagi setiap divisi maka pada akhirnya kinerja manajerial dapat meningkatkan laba perusahaan.

Pengujian hipotesis gaya kepemimpinan memperkuat hubungan antara partisipasi penyusunan anggaran terhadap kinerja manajerial menghasilkan nilai $\mathrm{t}$ hitung sebesar 1,480 dan nilai signifikansi sebesar 148. Dapat disimpulkan bahwa hipotesis 3 ditolak. Hal ini mendukung penelitian (Nor, 2007) gaya kepemimpinan bukanlah merupakan kesesuaian terbaik dalam mempengaruhi penyusunan anggaran terhadap kinerja manajerial. Bagi karyawan gaya kepemimpinan atasan tidak mempengaruhi kinerja.

Hipotesis komitmen organisasi memperkuat hubungan antara partisipasi penyusunan anggaran terhadap kinerja manajerial memiliki nilai $\mathrm{t}$ hitung sebesar 0,443 dan nilai signifikansi sebesar 0,660 dapat disimpulkan bahwa hipotesis 4 ditolak. Penemuan ini sejalan dengan penelitian (Suardana dan Suryanawa, n.d) Interaksi antara partisipasi penyusunan anggaran dan komitmen organisasi tidak signifikan terhadap kinerja manajerial. Hal ini tidak sejalan dengan penelitian (Ratri, 2010) komitmen organisasi positif dan signifikan mempengaruhi hubungan antara partisipasi penyusunan anggaran dan kinerja manajerial. Hal ini dimungkinkan hanya adanya keterlibatan saja namun tidak ada loyalitas. Berkomitmen tidak mempengaruhi kinerja karena berpartisipasi bagi karyawan dalam penyusunan anggaran sudah menjadi tanggung jawab dan harus dilakukan sepenuh hati.

Pada pengujian hipotesis motivasi memperkuat hubungan antara partisipasi penyusunan anggaran terhadap kinerja manajerial dapat diketahui nilai $\mathrm{t}$ hitung sebesar 0,910 dan nilai signifikansi sebesar 0,369 dapat disimpulkan bahwa hipotesis 5 ditolak. Hal ini tidak sejalan dengan penelitian (Srihantoro, 2010) motivasi memoderasi hubungan antara partisipasi anggaran terhadap kinerja manajerial. Ada kemungkinan bahwa tidak perlu adanya motivasi timbal balik yang harus didapat karena pekerjaan tersebut merupakan tanggung jawabnya. 


\section{Simpulan dan Saran}

Berdasarkan hasil analisis data mengenai pengaruh partisipasi penyusunan anggaran terhadap kinerja manajerial dengan desentralisasi, gaya kepemimpinan, komitmen organisasi dan motivasi sebagai variabel moderating (studi pada hotel di Kota Yogyakarta), maka dari hasil penelitian ini dapat disimpulkan bahwa hipotesis partisipasi penyusunan anggaran pada tidak berpengaruh terhadap kinerja manajerial, hipotesis desentralisasi berhasil memperkuat hubungan partisipasi penyusunan anggaran terhadap kinerja manajerial, hipotesis gaya kepemimpinan tidak berhasil memperkuat hubungan partisipasi penyusunan anggaran terhadap kinerja manajerial, hipotesis komitmen organisasi tidak dapat memperkuat hubungan partisipasi penyusunan anggaran terhadap kinerja manajerial, hipotesis motivasi tidak berhasil memperkuat hubungan partisipasi penyusunan anggaran terhadap kinerja manajerial. Ada kemungkinan bahwa tidak perlu adanya motivasi timbal balik yang harus didapat karena pekerjaan tersebut merupakan tanggung jawabnya.

Saran yang dapat diberikan berdasarkan hasil penelitian ini yaitu dapat menambahkan variabel moderating lain dalam penelitian selanjutnya.

\section{Referensi}

Adrianto, Yogi. 2008. Analisis pengaruh partisipasi penyusunan anggaran terhadap kinerja manajerial dengan kepuasan kerja, job relevant information dan kepuasan kerja sebagai variabel moderating (Studi Empiris Pada Rumah Sakit Swasta di Wilayah Kota Semarang). Tesis. Semarang: Universitas Diponegoro.

Andarini, Raden Roro. 2005. Motivasi, gaya kepemimpinan dan desentralisasi sebagai variabel pemoderasi hubungan antara partisipasi penyusunan anggaran dengan kinerja pada organisasi sektor publik. Studi empiris pada pemerintah daerah sePropinsi DIY. Tesis. Yogyakarta. Universitas Gadjah mada.

Fany, 2010, Kelas Tambahan (online). Didapatkan: http://kelastambahan. wordpress. com/ 2010/04/26/pengertian-anggaran-pengaggaran-tujuan-anggaran-manfaat-dan-kelemahananggaran-fungsi-dan-macam-anggaran/

Ghozali, Imam. 2006. Aplikasi Analisis Multivariate dengan program SPSS. UNDIP: Semarang

Halim, Abdul, Achmad Tjahjono dan Muhammad Fakhri Husein. 2000. Sistem pengendalian Manajemen. Yogyakarta. Upp STIM YKPN

Halim, Abdul dan Bambang Supomo 1990. Akuntansi Manajemen. BPFE Yogyakarta

Hanafi, Mamduh M. 2003. Manajemen. Upp amp YKPN

Hansen, Don R, Maryanne M. Mowen dan Ancella A. Hermawan 2000:65). Akuntansi Manajemen. Jakarta: Erlangga

Hapsari, Winda Arum dan Murtanto. 2005. Pengaruh partisipasi penyusunan anggaran terhadap kinerja manajerial dengan desentralisasi dan karakteristik sistem informasi akuntansi manajemen sebagai variabel moderating Simposium riset ekonomi II Surabaya (november), Hal. 5

Harmonis, Nirta. 2011. Pengaruh Partisipasi Anggaran dan Komitmen Organisasi terhadap Kinerja Manajerial pada Dinas Pendidikan Kabupaten Musi Banyuasin. Skripsi. Yogyakarta: Universitas Ahmad Dahlan

Lapuga, Reska Lefa. 2011. Analisis budaya organisasional dan gaya kepemimpinan di PT Bank DKI: Aplikasi instrumen organizational culture assesment dan management skill assessment. Thesis. Yogyakarta: Universitas Gadjah mada 
Nor, Wahyudin. 2007. Desentralisasi dan gaya kepemimpinan sebagai variabel moderating dalam hubungan antara partisipasi penyusunan anggaran dan kinerja manajerial. Jurnal. Makassar: Universitas Palangka Raya

Poerwati, Tjahjati. 2001. Pengaruh partisipasi penyusunan anggaran terhadap kinerja manjerial: Budaya organisasi dan motivasi sebagai variabel moderating. Tesis. Semarang: Universitas Diponegoro

Ramdhani, Ardiansyah. 2011. Pengaruh gaya kepemimpinan kepala ruang terhadap kepuasan kerja perawat (studi kasus di Rumah Sakit Jasa Kartini Tasikmalaya). Tesis. Yogyakarta: Universitas Gadjah mada

Ratri, Nanda Hapsari Ayuning. 2010. Pengaruh partisipasi penyusunan anggaran terhadap kinerja manajerial dengan komitmen organisasi dan locus of control sebagai variabel moderating (studi kasus pada pt adhi karya (persero) tbk. divisi konstruksi I). Skripsi. Semarang: Universitas Diponegoro

Rosmayanti, Nina. 2011. Pengaruh partisipasi anggaran, Komitmen Organisasi dan motivasi terhadap kinerja manajerial pada PT Telkom di Yogyakarta. Skripsi. Yogyakarta: Universitas Ahmad Dahlan

Srihantoro, Sigit. 2010. Pengaruh Partisipasi Anggaran terhadap Kinerja Manajerial dengan Motivasi sebagai Variabel Moderating studi pada Universitas Ahmad Dahlan. Skripsi. Yogyakarta: Universitas Ahmad Dahlan

Sule, Erni Tisnawati dan Kurniawan Saefullah. 2005. Pengantar Manajemen. Jakarta. Prenada Media Jakarta.

Windari, Asli. 2011. Pengaruh kecerdasan emosional terhadap tingkat pemahaman akuntansi dengan kepercayaan diri sebagai variabel pemoderasi (Studi pada Universitas Ahmad Dahlan Yogyakarta).Skripsi: Yogyakarta. universitas Ahmad Dahlan. 